a mystical excess. The world about us grows, it is true, more and more a dance of phantom formulæ on the points of dial-needles-the very stuff of dreams. Yet there are dreams and dreams. Some cohere and work; others do not. Incoherence was the weakness in the romanticism of Shelley or Victor Hugo ; it is the romanticism of Homer or Hardy that is more enduring. Though dreaming, they imposed order and consistency even on their fantasies. Classicism, realism, romanticism, are all extremesthe three points of a triangle within which lies inscribed the magic circle where walk the greatest masters.

\section{Parliamentary Science Committee}

At the annual meeting of the Parliamentary Science Committee held at the House of Commons under the presidency of Sir Arnold Wilson on December 5, the following officers were elected : President, The Right Hon. the Earl of Dudley; Chairman, Sir Arnold Wilson, M.P. ; Vice-Chairman, Prof. B. W. Holman; Deputy-Chairman, Mr. Alan E. L. Chorlton, M.P.; Hon. Secretary and Treasurer, Mr. H. W. J. Stone. The honorary secretary's annual report discloses that representative scientific and technical institutions continue to affiliate to the Committee. During the 1934-35 session, questions were asked in Parliament concerning agricultural and horticultural research, interchangeability of water supplies, the Intermational Locust Conference, milk pasteurisation, aeronautical engines (output), the gas grid scheme, the possibility of constructing earthquake-proof buildings in India, the research powers of the agricultural marketing boards, technical education and grants for industrial and agricultural research. Members of the Committee took an active part in the debates on the Herring Industry Bill and the Metropolitan Water Board General Powers Bill. Looking to the future, the Committee contemplates consideration in the near future among other things of such widely diverse subjects as the endowment of research, the finance of industrial research, income tax exemption on industrial research, patent legislation reform and the remission of death duties on bequests for research. The Committee compiles from Hansard and other sources a monthly summary of all scientific and technical matters considered in Parliament. The third volume of "Science in Parliament" has just been completed, and issued with a cross-reference index. Owing to the coming demolition of the Adelphi, the Committee is moving to Granville House, Arundel Street, Strand, W.C.2, on January 1.

\section{The Imperial Cancer Research Fund}

AT a meeting of the General Committee of the Imperial Cancer Research Fund held on December 4, the Duke of Bedford presiding, the thirty-third annual report of the Fund, dated 1934-35, was presented. A tribute was paid to Dr. J. A. Murray, who retired on October 1 after holding the directorship of the Fund since 1915, and who is succeeded by Dr. W. E. Gye. Dr. Gye in his report surveyed the scientific activities of the Fund since its inception, and referred to the work now in progress. The bearing of the researches upon tar cancers of mammals, and of the malignant sarcoma of fowls, the virus of which is a filterable one, on problems of human cancer was discussed, and Prof. J. McIntosh's experiments upon tar cancers of the fowl were summarised. The lastnamed tumours can at first be transmitted only by transplantation of a portion of the growth, but after transmission by this method for a few generations, it appears possible to transmit them by means of cell-free filtrates, that is, the virus becomes a filterable one comparable to that of the fowl sarcoma. The honorary treasurer, Sir H. J. Waring, reported that the Fund had a surplus of $£ 7,568$ for the year, and that legacies, donations and subscriptions all showed an increase over 1934. At the same time, the work is expanding, and expenses are likely to increase in the future, and he, therefore, made an appeal for additional contributions to the Fund. Dr. Gye, in summarising the present position of cancer research, said : "So far from there being any justification for pessimism, laboratory workers can all feel hopeful that the rapid progress now being made will lead to the solution of the primary problems of cancer".

\section{Minerals and their Utilisation}

SIR Thomas Holland, principal and vice-chancellor of the University of Edinburgh, propounded some very pertinent questions in proposing the toast of the profession of chemistry at the Ramsay Chemical Dinner held in Glasgow on December 6 . Sir Thomas said that some of the problems which have been baffling geologists for a long time are really problems for the chemist. In the early days, geologists were content with a knowledge of the principal constituents of minerals, and based their classifications on these. But it has become evident that, in some cases, it is the smaller constituents of a mineral which are the most important. With civilisation has grown the desire for the use of metals, and this desire has increased and will continue to increase until the supply of metals has been exhausted. What the geologist is most interested in and what he wants the help of the chemist to solve are, therefore, the laws which control natural deposits. These reactions of Nature have gone on for countless ages of time, and have produced local concentrations of minerals. We produce annually about 50,000 tons of nickel and 1,500,000 tons of copper, and yet the crust of the earth contains about twice as much nickel as copper. Our production of lead is about the same as that of copper, and the available supplies of lead are only one fifth of those of copper and therefore one tenth of those of nickel. Zinc, of which we produce more than 100,000 tons a year, is only half as abundant as copper, and we use three times as much tin as nickel, though the supplies of nickel are 50-100 times those of tin. There is surely something wrong in this relationship. The different habits of rocks in showing that varying tendency towards rearrange. ment of their constituents open up problems in physical chemistry which are still largely obscure. 